\title{
Oral Tradition as a Source for Digging Up the History of Parakan as a Heritage City
}

\author{
Purwantiasning Ari Widyati ${ }^{*}$, Kurniawan Kemas Ridwan ${ }^{2,}$ Sunarti Pudentia Maria Purenti Sri ${ }^{3}$ \\ ${ }^{1}$ Faculty of Engineering, Department of Architecture, Universitas Indonesia, Kampus UI Depok, Indonesia \\ ${ }^{1}$ Faculty of Engineering, Department of Architecture, Universitas Muhammadiyah Jakarta, Jalan Cempaka \\ Putih Tengah 27, Jakarta 10510, Indonesia \\ ${ }^{2}$ Faculty of Engineering, Department of Architecture, Universitas Indonesia, Kampus UI Depok, Indonesia \\ ${ }^{3}$ Faculty of Humanity, Universitas Indonesia, Kampus UI Depok, Indonesia
}

\begin{abstract}
This research was aimed to explore the history of Parakan City, a small city of Indonesia, located in Central Java. Parakan City has been regarded as a heritage city in Central Java and is well known as a Bambu Runcing City. Bambu Runcing is a sharpened bamboo that has been used as a traditional weapon in the past hundred years in Indonesia. This research was to conduct in oral tradition as a source for digging up the history of Parakan, particularly the reason why the community of Parakan using the words "Bambu Runcing" as a brand name for the city. This research was also to describe to what extent the community in having a strong attachment to the founder of Bambu Runcing known as KH Subuki. Some relevant and credible sources were interviewed using this oral tradition, and some of them are the second and third generation of KH Subuki.
\end{abstract}

Keywords: Oral tradition, history, Parakan, Heritage City, Bamboo Runcing City

\section{Introduction}

There are many kinds of literature that have discussed about conservation and preservation and its relation with urban heritage. All the issues of conservation, preservation, urban heritage particularly all objects which related to the past cannot be separated with the history of those objects themselves. The researchers have done some studies about conservation as well as urban heritage and the issues which related to it. This research is a part of the study that the researchers have done with different points of view and different approaches.

Generally, in Indonesia, there are a lot of historical sites that have been designated as a historical area that should be preserved and conserved. This imitative is one of the government's efforts to maintain and preserve Indonesian heritage. According to Undang-Undang No. 11 Tahun 2010 about Cagar Budaya (Cultural Heritage), Cagar Budaya could be defined as a cultural heritage which includes "Benda Cagar Budaya - Object Heritage", "Bangunan Cagar Budaya - Building Heritage", "Struktur Cagar Budaya- Structure Heritage", "Situs Cagar Budaya"-Sites Heritage", and "Kawasan Cagar Budaya"-Areas Heritage", either on a ground and or in a water which should be preserved their existence because they have a significant value for history, science, education, religion and or culture through designation process [1].

\footnotetext{
* Corresponding author: arwityas@yahoo.com
} 
One of the historical areas in Indonesia that have been designated as a Heritage City is Parakan, a a small city in Central Java, Indonesia. Parakan is unknown very well by the people of Indonesia because it is only small city and begins to know since the central government has designated the city to become a Heritage City in 2015 through Piagam Komitmen Penataan Pelestarian Kota Pusaka.

The city of Parakan used to be a trade city in the colonial era, the city very well known as a city of tobacco, coffee and spices, although not all Indonesia people know Parakan very well. Recently, Parakan has been famous among teenagers because of its coffee and its scenery as well, according to the movie of "Filosofi Kopi" which has been taken place as a setting in the film.

On the other hand, Parakan has a history that still not well known by Indonesian people. Parakan has been famous because of the history of the pioneer of Bambu Runcing, known as Kyai Haji Subuki or Kyai Bambu Runcing or Jendral Bambu Runcing. In the colonial era, Parakan was very well known by Indonesian soldier as a city of Bambu Runcing. Many Indonesian soldiers from other cities came to Parakan to meet Kyai Haji Subuki and asked him to make Bambu Runcing as a traditional weapon to fight with the Dutch.

This research will explore the history of Parakan, particularly the history of Parakan in colonial era while Bambu Runcing had been established for a traditional weapon from time to time. The main issue of this study is the lack information about Parakan in written sources or literature sources. Thus, the researcher conducted an oral tradition as an approach to dig up the history of Parakan, particularly the history of Kyai Bambu Runcing and the activities inside the city of Parakan.

\section{Research method}

This research is historical research which will explore the history of Parakan as a heritage city. The researcher will conduct descriptive qualitative research which uses a narrative descriptive method to describe the case study in both physical and non-physical aspects. As historical research, the researcher will undertake oral tradition from the local community as a primary source to dig up the history of Parakan.

\section{Oral tradition as a history itself}

Oral tradition, be it in the form of story, song, or poetry, accompanies almost every aspect of community's life, relieving the boredom of monotonous work, celebrating and remembering the deeds of historical and mythological characters and passing the long winter nights [2]. Grant (2014) also mentioned that oral tradition was not simply used as a form of entertainment or education, it was also employed to pass down valuable information concerning the status and rights of individuals [2].

On the other hand, Vansina (2006) has defined oral tradition as verbal testimony transmitted from one generation to the next one or a later one, which is more precise. He has claimed that oral tradition as an appropriate historians' source and defined himself as a genuine historian. Oral tradition has been regarded as an approach for the historian in digging up some historical event through the local community, and this approach should be used to study tradition and its relation to the social system [3].

As mention before, that the researcher has realized that this study is lack of evidence from the documentation, photograph, and maps, literature and written history about Parakan. Thus, the researcher has designated an oral tradition as an approach. It refers to Vansina (2006) that mention: "oral tradition exclusively consists of hearsay accounts, that is, testimonies that narrate an event which has not been witnessed and remembered by the informant himself, but which he has learned about through hearsay" [3]. By using some information from a significant respondent, the researcher will dig up the history of Parakan particularly the history of Parakan as Bambu Runcing City. The researcher will start to dig up the history by interviewing some respondents from the generation of 
Kyai Haji Subuki or Kyai Bambu Runcing from the third to the fourth generation. The researcher also involved some academics, historians and local community who know very well about the history of Parakan.

The researcher understood very well that oral tradition has been regarded as a source of knowledge about the past (the history). This approach could use the traditions which could occupy a special place among the various kinds of historical sources. There is a significant value of oral tradition as a historical source. According to Vansina (2006), this oral tradition approach in some traditional region used to be used as oral testimonies concerning the past which are transmitted from one person to another, from one generation to another. Vansina has also mentioned that there are a lot of historical sources including the ancient one that based on oral tradition, particularly some areas which have no written documentation about their history. To construct the past or the history, the local community tries to use oral tradition from one generation to another generation. This condition is very vulnerable lost because there is always a generation that will not survive and able to continue the tradition. To handle this condition, it will need a revitalization of this oral tradition approach [3]. Pudentia in her article (2015) has mentioned that there is an effort to make oral tradition sustain, in this case, folklore, it is known as a revitalization of oral tradition. The highest effort in doing this revitalization is by involving all parties that support the oral tradition. The primary thing that shows the succeeded revitalization is if there is significant change within the community if the oral tradition could be maintained through the community [4].

Although, the researcher will use limited written sources to compare with the history from oral tradition approach. The researcher will analyze the limited information from written sources with the information from designated respondents using interpretation approach. The researcher has interviewed some respondents from academics, historian, and local community particularly the generation of Kyai Haji Subuki. They have explained the history of Parakan particularly the history of Bambu Runcing with oral tradition, some information they have gotten from their parents or their grandparents. The history of Parakan will always remind in their mind and heart from one generation to another generation until present days.

The researcher believes that this oral tradition approach will broaden up the knowledge of this study and will improve the quality of this research as well. Also, by using this oral tradition approach, the researcher will understand that an architectural research in historical method could be completed with this approach. It was mentioned by Grant [2] that limited archaeological engagement with the oral tradition presents both an opportunity and a challenge. The opportunity is for exploring of new ways to approach the post-medieval period for the first time and the challenge of knowing where to begin. According to that statement, the researchers also believe that the word "archaeological" is not only for archaeologist but also for all researchers in all fields.

Jones and Russell (2012) have mentioned that the relation between orality and writing in the context of social memory is of course particularly important in respect to historical archaeology, a field that has long been preoccupied with the relationship between material culture and texts. They also have stated that social memories are composed of the fragmented stories that surround specific places and events, which are passed around within and between generations [5].

Moreover, Bernheim in Vansina (1950) has explained that oral tradition could be distinguished into five categories as follow:
a. narrative,
b. legend,
c. anecdote,
d. proverb and
e. historical lays.

This research is a narrative oral tradition approach which is involving some respondents as a source of history, and they will tell the history in narrative method. Bernheim (1950), also stated that in narrative oral tradition, it will be derived into three categories: first hand, eyewitness report and other sources which including second hand, hearsay reports and event which is treated as legends [3]. 
The whole research, the researcher will try to discuss the history of Parakan from oral tradition approach that will be divided into three parts, Parakan before Islam Era (Hindu Era), Parakan after Islam Era, and Parakan as a place to start the revolution of Indonesia soldier in fighting back the colonial. The first and second part, the researcher has interviewed some academics and historians to get some information about the history of Parakan before and after Islam Era. And the third part, the researcher has interviewed some witnesses and generation of a significant figure such as KH Subuki as a pioneer of Bambu Runcing, the sharpened bamboo of a traditional weapon for Indonesia soldier. But in this paper, the researcher will only discuss the third part, which is the discussion of Parakan through the history of Parakan as the City of Bambu Runcing.

\section{Findings and results}

This research has been conducted for twelve-month process in the field. The researcher has spent the time with some significant respondents to dig up the history of Parakan, particularly the history of Parakan as the City of Bambu Runcing. Before choosing some significant respondents, the researcher has tried to make a family tree of Kyai Haji Subuki, to explore and relate the generation of him from the second, third and fourth. By using the information from some generation of Kyai Haji Subuki, the researcher has formed the family tree into separated diagrams because there are a lot of member of the families that should be mentioned in each diagram. From the figure 1, it shows the first generation and second generation of Kyai Haji Subuki. The first generation shows that he has 3 sons and 4 daughters. All of this first generation have been passed away since long time ago. The second generation shows that Kyai Haji Subuki has 31 grandsons and granddaughters from 6 sons and daughters, because his last daughter named Kulsum, she had no children. From this second generation, there is only one still alive, it is his granddaughter named Chulaefah. She still alive and lives in Parakan. She is one of the researcher's significant respondent. Although, there is only small information that the researcher has collected from her, because she is too old to stay fresh and has a long conversation. The diagram of the family tree of Kyai Haji Subuki could be seen as follows:

KYAI HAJI SUBUKI

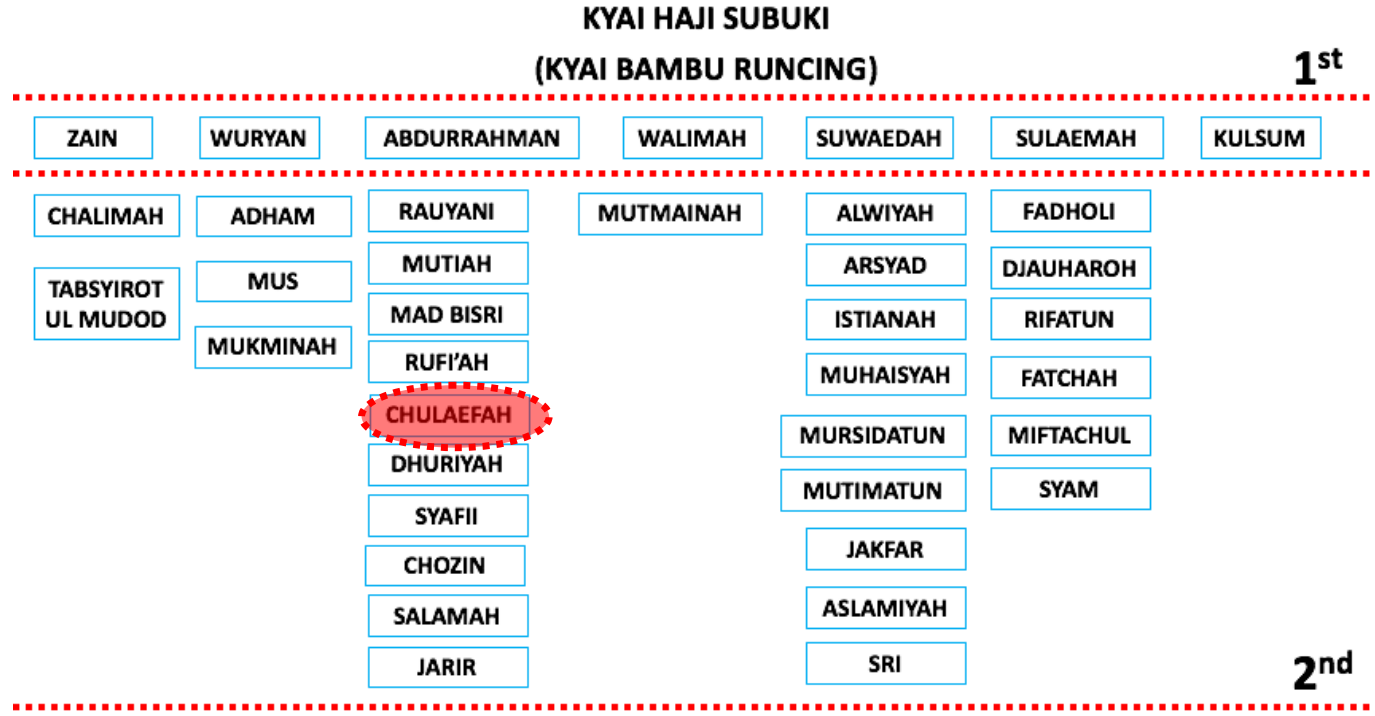

Fig. 1. The family tree of Kyai Haji Subuki's family, that shows the first generation (7 sons and daughters) and the second generation (31 grandsons and granddaughters)

Source : analysis result, 2018 


\section{KYAI HAJI ABDURRAHMAN BIN SUBUKI}

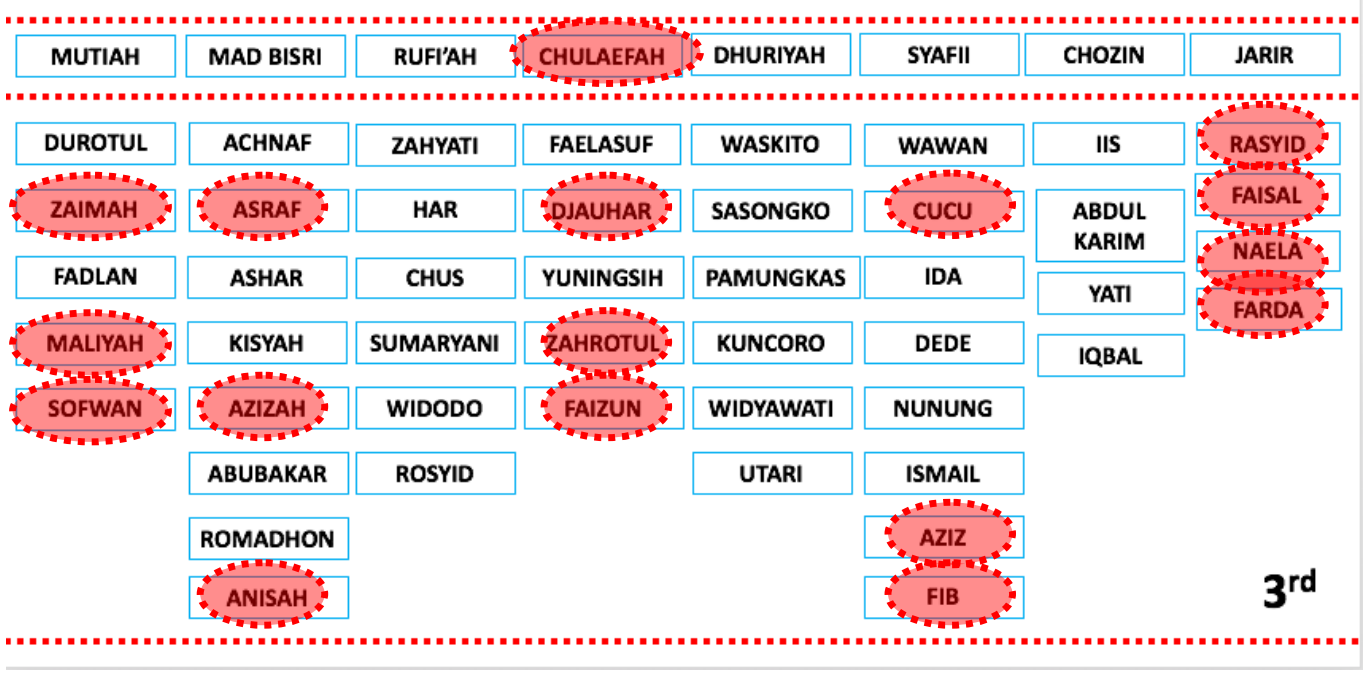

Fig. 2. The family tree of Kyai Haji Subuki's family, that shows the second generation of him name Kyai Haji Abdurrahman bin Subuki, the son that had been killed by the Dutch because the Dutch had the wrong target. He has 10 sons and daughters, but 2 of them had passed away since baby. Thus, there are only 8 left that has been mentioned in the above family tree.

Source : analysis result, 2018

On the other hand, the researcher also has interviewed historians Sutrisno Murtiyoso, Akfriful Basori, Subkhan Kamidi who also founders of Nata Parakan Luwes (the community group that concern about the development and the conservation of Parakan as a Heritage City). Some respondents from local community also have been interviewed by the researcher to compare about one information to another. 
The information that have been collected by the researchers could be detailed as follow :

\begin{tabular}{|c|c|c|c|}
\hline No & Category & Respondents & Output \\
\hline 1 & First Hand & NA & NA \\
\hline 2 & report & $\begin{array}{l}\text { Chulaifah } \\
\text { (Daughter of KH } \\
\text { Abdurrahman-son of } \\
\text { KH Subuki) }\end{array}$ & $\begin{array}{l}\text { The story how the soldier of } \\
\text { Dutch has killed KH Abdurrahman son } \\
\text { of KH Subuki in his house because the } \\
\text { Dutch killed the wrong person (should } \\
\text { be KH Subuki as a target) }\end{array}$ \\
\hline \multirow[t]{6}{*}{3} & \multirow[t]{6}{*}{$\begin{array}{l}\text { Second } \\
\text { Hand, Hearsay } \\
\text { Reports }\end{array}$} & $\begin{array}{l}\text { Asrof bin } \\
\text { Bisri (Grandson of } \\
\text { KH Subuki) }\end{array}$ & $\begin{array}{l}\text { The story of Barisan Muslim } \\
\text { Temanggung, the strory of Bambu } \\
\text { Runcing and the story of KH Subuki as } \\
\text { a pioneer of Bambu Runcing }\end{array}$ \\
\hline & & \begin{tabular}{l}
\multicolumn{2}{c}{ Binawan } \\
Muhammad \\
(Grandson of $\mathrm{KH}$ \\
Subuki)
\end{tabular} & $\begin{array}{l}\text { The story of KH Subuki as a } \\
\text { pioneer of Bambu Runcing, and how } \\
\text { local community has encourage the } \\
\text { family to propose KH Subuki as } \\
\text { National Hero }\end{array}$ \\
\hline & & $\begin{array}{l}\text { Akriful Basori } \\
\text { (local community and } \\
\text { historian) }\end{array}$ & $\begin{array}{l}\text { The history of Parakan from } \\
\text { Mataram Hindu Era until Mataran Islam } \\
\text { Era and the coming of Diponegoro } \\
\text { soldier until the establishment of } \\
\text { Parakan as Kauman (the city of 'kaum") }\end{array}$ \\
\hline & & $\begin{array}{l}\text { Sutrisno } \\
\text { Murtiyoso (local } \\
\text { community, historian } \\
\text { and lecturer) }\end{array}$ & $\begin{array}{l}\text { The history of Parakan as the } \\
\text { city of "kaum" and the city of Bambu } \\
\text { Runcing, the morphology of Parakan } \\
\text { from time to time }\end{array}$ \\
\hline & & \begin{tabular}{lr}
\multicolumn{2}{c}{ Subkhan } \\
Kamidi & (local \\
community, historian \\
and Nata & Parakan \\
Luwes - & local \\
community & \\
organization & \\
\end{tabular} & $\begin{array}{l}\text { The story of Parakan from } \\
\text { Mataram Hindu Kuno Era until } \\
\text { Mataram Islam Era, the history of } \\
\text { Parakan as Karangtengah village, the } \\
\text { location of Kayumwungun encrypted, } \\
\text { the prove that Parakan was a city of } \\
\text { "rakai" in Hindu Era }\end{array}$ \\
\hline & & $\begin{array}{l}\text { Zaimah } \\
\text { (Grand daughter of }\end{array}$ & $\begin{array}{l}\text { The story of Parakan in colonial } \\
\text { era when the soldier come and go to }\end{array}$ \\
\hline
\end{tabular}




\begin{tabular}{|c|c|c|c|}
\hline No & $\begin{array}{l}\text { Cate } \\
\text { gory }\end{array}$ & $\begin{array}{ll} & \text { Responde } \\
\text { nts } & \\
\end{array}$ & Output \\
\hline \multirow[t]{5}{*}{3} & \multirow[t]{5}{*}{$\begin{array}{l}\quad \mathrm{Sec} \\
\text { ond Hand, } \\
\text { Hearsay } \\
\text { report }\end{array}$} & $\begin{array}{l}\text { Sofwan } \\
\text { (grand son of KH } \\
\text { Abdurrahman- } \\
\text { son of } \mathrm{KH} \\
\text { Subuki) }\end{array}$ & $\begin{array}{l}\text { The story of KH Subuki as pioneer of } \\
\text { Bambu Runcing }\end{array}$ \\
\hline & & $\begin{array}{l}\text { Adilin } \\
\text { Basiri (local } \\
\text { community) }\end{array}$ & $\begin{array}{l}\text { The story of how Barisan Muslim } \\
\text { Temanggung has been established by some Kyai } \\
\text { in Parakan including KH Subuki }\end{array}$ \\
\hline & & $\begin{array}{l}\text { Zatun } \\
\text { (local } \\
\text { community) }\end{array}$ & $\begin{array}{l}\text { The story of KH Subuki, the story of } \\
\text { Bambu Runcing and the story of how indonesian } \\
\text { soldier came to Parakan to make Bambu Runcing }\end{array}$ \\
\hline & & $\begin{array}{l}\text { Anisa } \\
\text { (grand daughter } \\
\text { of KH Subuki) }\end{array}$ & $\begin{array}{l}\text { The story of } \mathrm{KH} \text { Subuki, the story of } \\
\text { Parakan as city of Bambu Runcing and the family } \\
\text { tree of KH Subuki }\end{array}$ \\
\hline & & $\begin{array}{l}\text { Laela } \\
\text { (grand daughter } \\
\text { of KH Subuki) }\end{array}$ & $\begin{array}{l}\text { The story of KH Subuki, the story of } \\
\text { Parakan as city of Bambu Runcing and the family } \\
\text { tree of KH Subuki }\end{array}$ \\
\hline
\end{tabular}

From the information that the researcher has been collected, this research could fulfill the objectives of the research. The researcher could formulate the history of Parakan chronologically particularly the history of Parakan since the colonial era. As Basori has mentioned in the interview, Parakan has its own history before the name of the city of Parakan came up until the town known as Parakan. As an academic person, Basori has told the story of Parakan chronologically and it was apparent to be understood very well by the researcher. Basori also mentioned about the history of Kyai Haji Subuki, how he had came for the first time to Parakan, and how he had tried to gather all the Indonesian soldiers and promoted Bambu Runcing as a traditional weapon to fight the Ducth.

The story from Basori, also has been supported by the information from all the family of Kyai Haji Subuki either from the second generation, third generation as well as fourth generation. The researcher believes that this tradition to transfer the information about the history of Kyai Haji Subuki, Bambu Runcing and Parakan has been preserved very well among family, and local community of Parakan. Another historian, name Sutrisno Murtiyoso who used to live in another part of Kauman, Parakan (the place of Kyai Haji Subuki), also has supported this information. He has mentioned how down to earth was Kyai Haji Subuki in the colonial era. He had always thought about the community without doubt. Subkhan Kamidi, as local community has stated that as a founder of Nata Parakan Luwes (NPL), this community group tries to preserve Parakan as a Heritage City. And one of the agenda is to keep the history of Parakan as a city of Bambu Runcing with Kyai Haji Subuki as the significant person. Recently, since 2015, Nata Parakan Luwes has tried to promote Kyai Haji Subuki as a national hero, referring to his braveness and his spirit in the colonial era by promoting Bambu Runcing as a weapon. 
One of the activities of KH Subuki and Indonesian soldier is to produce Bambu Runcing as many as they can. One of the rituals is to put the bamboo in the pool with full of water, also to put the soldier as well for 24 hours in the pool with full of water (and the temperature of Parakan always under 20 degree). This activity is to make the soldier get strength from Allah SWT, and they were staying in the pool for 24 hours, the pool itself is located inside the Masjid Al Barokah. This is the history why the mosque has been known well as Bambu Runcing Mosque. The transformation of the Mosque has been changed significantly from the colonial era to post-colonial era. Before independence day, the Mosque of Bambu Runcing has its traditional form and has a similarity with many Javanese Mosque with a pyramid roof known as Limasan Roof. Unfortunately, it did not stay longer, because in the 20 s century the form of the mosque has been transformed become more modern with a dome roof (see figure 3 and 4).

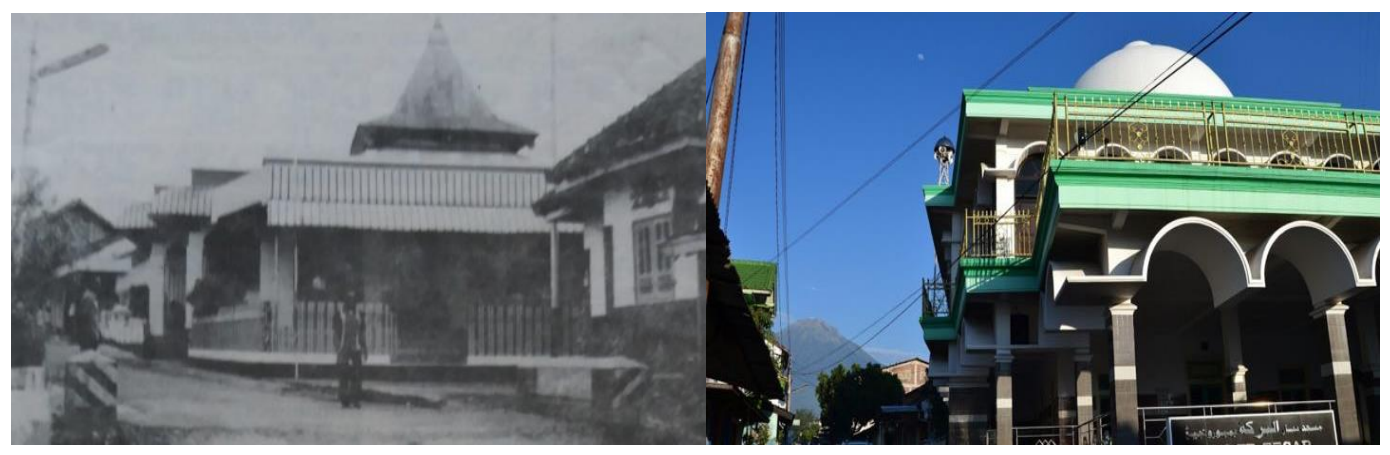

Fig. 3. and Fig. 4.. Mosque of Al Barokah Bambu Runcing- Left-hand Side: the mosque in colonial era before renovation, Right-hand Side: the mosque in post-colonial era after major renovation. This mosque is one of historical place in colonial era for making sharpened bamboo as traditional weapon to fight the Dutch.

Source: Letf-hand side- Adilin Basiri (1940), Right-hand side-Private Documentation (2017)

Another historical object in Kauman, Parakan is the historical house of KH Subkhi, it is known as Omah Candi (Candi means an object that has become a heritage from old people to his generation, and Omah means house). This Omah Candi, has been changed significantly since 2012 after part of the house become a small restaurant. Omah Candi, that used to be a private house and never been opened for public except the middle terrace that used to be for "pengajian".

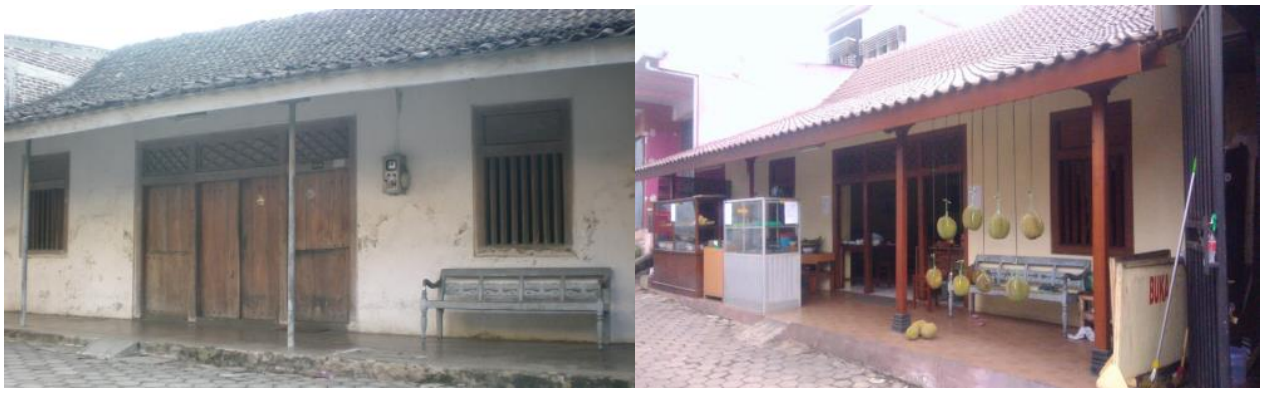

Fig. 5. and Fig. 6.. KH Subkhi's House- Left-hand Side: the house in colonial era before renovation, Right-hand Side: the house in post-colonial era after major renovation, it becomes a restaurant. This house is one of historical place in colonial era, the place of KH Subkhi (the pioneer of Bambu Runcing) for living and doing his activities during colonial era

Source: Letf-hand side- Adilin Basiri (1940), Right-hand side-Private Documentation (2017) 
After the renovation in 2010 and 2012, this Omah Candi has been opened for public for restaurant use and reseidential use at the back. The form of still has remain the same, there are big doors (4 parts of doors) in the middle of the façade, and still has two windows at the right and left (see figure 5 and 6 ).

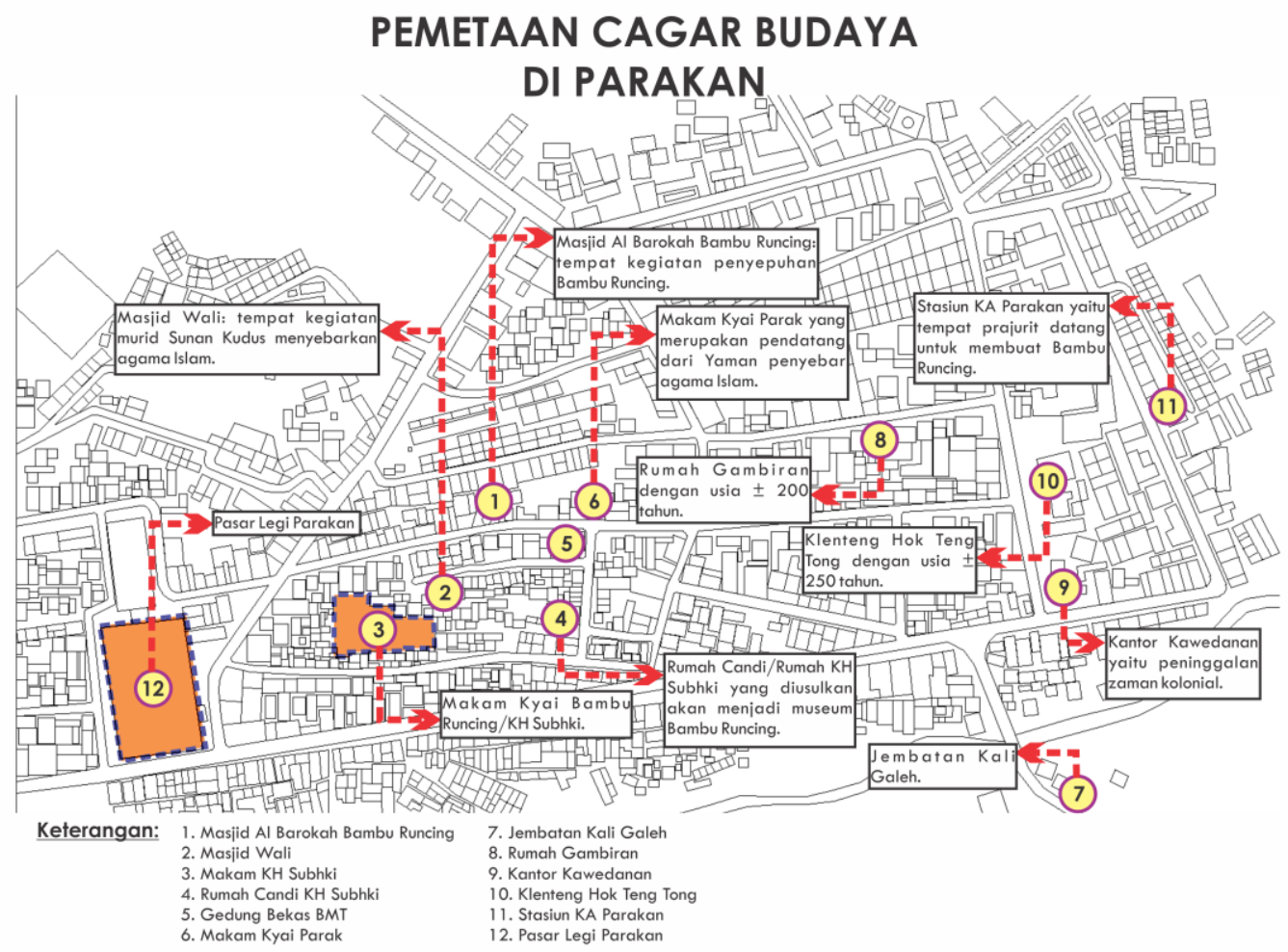

Fig. 7. The mapping of cultural heritage in Parakan that has been formulated by the researcher through the oral tradition approach to historians, local community and family of Kyai Haji Subuki.

Source: Analysis result, 2018

By interviewing the significant respondents, the researcher has collected all the information of the history of Parakan, particularly about the history of Parakan as a city of Bambu Runcing and a Heritage City. All the collected data has been formulated by the researcher into spatial mapping. Figure 7 shows that the researcher has formulated the mapping of cultural heritage in Parakan that has been collected from the significant respondent using oral tradition approach. The cultural heritage that has been shown in figure 7 are covered from Kauman areas and Pecinan (China Town) areas in Parakan. The cultural heritage include all the object which related to the history of Parakan either about the history of Bambu Runcing or the history about Parakan itself. On the other hand, figure 8 shows the spatial mapping of the activities of the Indonesian soldier in making Bambu Runcing in the colonial era. The activities of the soldier began from the Old Rail Station of Parakan and ended at Masjid Al Barokah Bambu Runcing (the Mosque of Bambu Runcing). The activities also involved some points auch as the house of Kyai Haji Subuki, Masjid Wali, and also the building of Barisan Muslim Temanggung. 


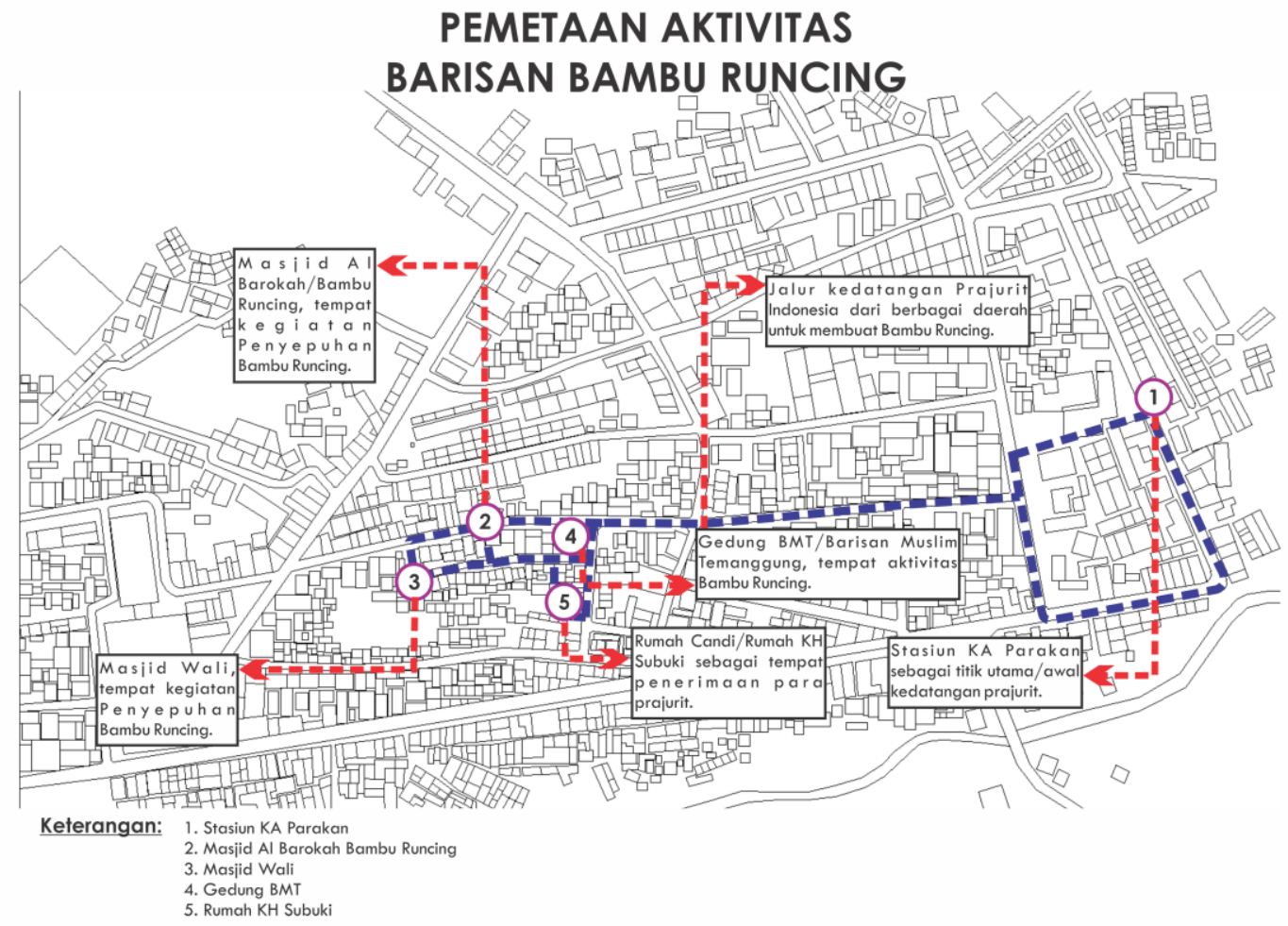

Fig. 8. The mapping of the activities the Indonesian soldier in making Bambu Runcing as a traditional weapon in the colonial era

Source: Analysis result, 2018

From all the above discussion it has been clear stated that oral tradition become a significant source history to dig up the history of Parakan. Researcher has proven this condition after doing some interviews with some significant and important respondents to hear the story of Parakan as city of "kaum", city of "Bambu Runcing" and heritage city. All the significant respondents have been chosen because they have an important role in Parakan, either as historian, observers, eyewitnesses, grandson and granddaughter of the significant person in colonial era (KH Subuki). The tradition to tell story from time to time in Parakan have been preserved within community of Parakan. The local community will not loose the story of Parakan particularly Parakan as a city of Bambu Runcing, because this term is not just a brand of the city, but this is a history that had been happened in Parakan especially in Kauman.

\section{Conclusion}

Conservation and preservation of historical building cannot be separated from their history. The significance of historical building to be preserved and to be conserved shoul be refferred to their history. Old buildings that have so many historical value inside it, will have significancy to be preserved and conserved. One of an importance subject that have many relation with history are the community itself, particularly local community who live in surrounded area of conservation sites. Although, there is a main issue how to dig up the history of an area which is lack of literature and 
source of history. One of the solution is by using oral tradtion approach. By using oral tradition approach, this research about Parakan could be defined chronologically.

This research was based on several years of study from 2016 to 2019, which has now been incorporated as part of a dissertation for a doctoral program. This research is a second year research project and its publication in the international conference has been funded by Universitas Indonesia under PITTA (Publikasi Internasional Terindeks untuk Tugas Akhir Mahasiswa UI) program year 2018, contract number: 2467/UN2.R3.1/HKP.05.00/2018.

\section{References}

1. Undang Undang Republik Indonesia No. 11 Tahun 2010 Tentang Cagar Budaya. Cultural Heritage. (2010)

2. Grant, Kevin James. And in Every Hamlet a Poet: Gaelic Oral Tradition and Postmedieval Archaelogy in Scotland. Historical Archaelogy: Archaelogy and the Oral Tradition: Case Studies from Britain and Beyond. Volume 48 No. 1. Pp. 30-45. (2014)

3. Vansina, Jan. Oral Tradition: A Study in Historical Methodology. Translated from French by HM Wright. Aldine Transaction: A Division of Transaction Publisher, New Brunswick, USA. (2006)

4. Pudentia, MPSS. (2015). Ketika Peneliti Harus Bercerita tentang Tradisi Lisan. In the Metodologi Kajian Tradisi Lisan, pp. 439-449. Asosiasi Tradisi Lisan. Yayasan Obor Indonesia.

5. Jones, Sian and Russell, Lynette. Archaelogy, Memory and Oral Tradition: An Introduction. International Journal of History Archaelogy. Volume 16 No. 2 June 2012. Pp. 267-283. (2012). 